\title{
Church-based organisations and their role in the support of older adults in Nnewi, South-east Nigeria
}

\author{
Samuel O. Ebimgbo ${ }^{1}$, Oscar N. Atumah ${ }^{2}$, \& Uzoma O. Okoye'1. \\ ${ }^{1}$ Department of Social Work, University of Nigeria, Nsukka, Nigeria \\ ${ }^{2}$ Department of Sociology, University of Abuja, Nigeria \\ Email:samuel.ebimgbo@unn.edu.ng
}

\begin{abstract}
Background: Despite increase in the number of older adults in Nigeria, and the health, social and economic implications that accompany this reality due to burden of care on families, little is known about the role of church-based organisations in the provision of support and care to older adults in Nigeria. The aim of this study was to explore the place of the church in the support and care of older adults.

Data Source and Method: Sample size of $(n=40)$ participants were recruited for the study. Focus Group Discussion and In-depth Interview were employed for data collection.

Results: The findings revealed that church-based organisations were a significant source of support for older adults; however, some of the support provided by church-based organisations was exclusively at the reach of older adults who are members of a particular church network.

Conclusion: The paper therefore recommends for an all-inclusive support and care for older adults by church-based organisations in the society, irrespective of the one's religious denomination.
\end{abstract}

Keywords: Church; Church-based organisations; Pragmatic roles; Social support; Older adults

\section{Introduction}

Old age, though the last stage in human transition, has not always been a negative course. This stage of life requires more social support and care, notwithstanding the level of economic well-being of the individual during early adulthood. Currently, the world is grappling with an upsurge in the population of older adults. This is not unconnected with the surge in life expectancy and decline in fertility rate which is largely a product of the improvements in living conditions and medical services (Kinsella and Phillips, 2005; Kulik et al, 2014). The increase in population of older adults is one of the major issues confronting developing countries including Nigeria. The United Nations (2012) report that population of Nigerians aged 60 years and above was 8.8 million in the year 2012; meanwhile this figure is projected to be 28 million by the year 2050. With this, in less than 37 years, population of Nigerian older adults will exceed the current population of Ghana and equally twice over the current population of Senegal (Togonu-Bickersteth and Akinyemi, 20I4). The implication is that Nigeria will experience dramatic increase in the number of older adults to be supported and cared for in the nearest future (Okoye, 2012).

Studies abound to show that social support and care has positive effects on the life satisfaction and well-being of older adults (Ahmad, 2016; Caetano,
Silver and Vettore, 20I3; Li, Ji and Chen, 20I4; Oluwagbemiga, 2016; Roh et al., 2015). On the contrary, inadequate social support is associated with lower general health and well-being, higher levels of emotional distress, more illness and higher mortality rates (World Health Organization [WHO], 2002). Inadequate social support and care also impinges on the physical, social and mental health of older adults. It decreases the use of health services, leads to poor functional capacity, increases somatic health problems and unhealthy behaviour, and exposes older adults to greater risk of cardiovascular disease. This can increase the risk of sleep problems, functional decline, and mortality (Costa et al., 20I I). Also, Bath and Deeg (2005) reported higher number of deaths among older adults with inadequate social support than among those with adequate social support in the form of networks of relationships and emotional support. Melchiorreet al. (20/3) reported that older adults who are isolated and who lack the desired social support and care are most likely to exhibit signs of depression and somatic complaints.

Older adults with insufficient social support and care are liable to poor cognitive abilities, lower life satisfaction, and higher levels of loneliness. Loneliness is one viable factor that can impair one's mental ability and life satisfaction (Rokach, Orzeck and Neto, 2004). Loneliness is related to negative physical health outcomes in older adults, including higher http://aps.journals.ac.za 
systolic blood pressure, elevated hormone levels, less restorative sleep that affects alertness and mood improvement and performance (Hawkley and Cacioppo, 2007). Older adults with insufficient social support are susceptible to making negative life choices (Dodson, 2009). Melchiorre et al. (20/3) found that low level of social support may constitute crucial risk for elder mistreatment, as a result of older adult's economic dependency to their support systems, especially the family caregivers. For a successful ageing, social support has been seen as a key component.

From the foregoing, it is evident that adequate social support plays an important role in the achievement of successful ageing. It has been shown that the availability of social support from churchbased organisations can minimize the problems affecting the emotional, physical, social, economic, and psychological well-being of older adults. For instance, Krause (2006) reveals that social support that is provided by fellow church members to older adults will always enable them to cope more effectively with the adverse effects of stressful life events. More so, social support received from members of the church reduces depressive symptoms and psychological distress (Chatters et al., 2015).

In the same vein, Krause and Hayward (2014) found that spiritual support from the church would offset the effects of functional disability on change in feelings of personal control over time. Other benefits associated with social support include opportunities to survive from diseases such as cancer, cardiovascular, inflammation and less effective immune system functioning (Holt-Lunstad, Smith and Layton, 20I0). Evidently, social support helps older adults to cushion the effects of diseases like functional disability and pains associated with arthritis (Evers et al., 2003). Although many studies in Nigeria have discussed the influence of social support on older adults from the networks of family members and close friends (Okoye, 2012; Okoye and Akinyemi, 2009; Okumagba, 20II; Oladeji, 20II; Sijuwade, 2008), little is known about the support and care provided by church-based organisations. This study attempts to attend to this significant gap by exploring the roles of church-based organizations in the support and care of older adults in Nnewi, South-east Nigeria.

\section{Literature review and theoretical framework}

Scholars have identified various roles credited to church-based organisations across the globe regarding social support and care for older adults. Within African American churches, church-based support networks provide significant amounts of assistance to their church members (Chatters et al., 2002; Taylor, Chatters and Levin, 2004; Taylor, Lincoln and Chatters, 2005). Some of these support and care provided by the church-based organisations are tangible support such as financial assistance, material provisions (food, clothes, food stuff etc), transportation, housing, job referrals. There are other non-tangible supports provided by churchbased organisations which include emotional support, information, counseling and advice (Taylor et al., 2005).

The African American churches also have actively been engaged in community services and outreaches in the areas of health, social welfare, education, community organizing and development (Billingsley, 1999; Lincoln and Mamiya, 1990). Health support programmes from church-based organisations which are associated with improved health behaviours among African American older adults include improved nutrition, physical activities/exercises, and cancer screening (Boehm et al., 1995; Campbell et al., 1999; DeHaven et al., 2004; Duan et al., 2000; Duru et al., 2010; Ellis and Morzinski, 2013). Also, Zimmer et al. (2016:377) noted that "the place of worship can play a supportive role particularly important for older persons who, in some countries, will be frequently living alone, could be lonely and may be experiencing frequent losses".

In Nigeria, financial and healthcare provisions for older adults remain some of the essential development programmes and major activities of church-based organisations. For instance, Mugweru (20II) posit that the Christian Health Association of Nigeria (CHAN) provides healthcare services at tertiary, secondary and primary levels to about $40 \%$ of the Nigeria population. Also, the Diocesan Development Services (DDS), of Idah Catholic Diocese, Kogi State is involved in activities that are aimed at improving the welfare and status of the poor through microcredit services (Baiyeri, 20I4). In the same vein, Dimelu, Salua and Igbokwe (2013) found that church-based organisations are among non-profit making, private organisations with laudable goals and programmes in the rural communities of Nigeria. To them, church-based organisations have positively influenced the socio-economic life of individuals in the rural areas of Nigeria. Some of the support and care they provide include finance, improved health care and sanitation.

Church-based organisations in Nigeria have equally in some cases played significant roles in addressing the plight of widows in the Nigerian society. Some church-based organisations such as Living Faith Church, Redeemed Christian Church of God, Four Square Gospel Church, and Christ Apostolic Church etc. have shown great concern by 
supporting the children of widows through scholarship in order to alleviate their plight (Zhiya, 2015). Also, some Pentecostal and Anglican Churches have positively and actively responded to the plight of widows through their pastoral and caring activities. These denominations assist some of their members who are widows as well as other widows of other religious denominations to find accommodation; organizing seminars and counseling sessions; providing welfare packages such as skill acquisition programmes, regular financial assistance, and food items (Agubuzu-Oyi, 20 I4; Zhiya, 20I5).

Several factors have been posited by scholars as the motivation for support and care to older adults from church-based networks. According to Krause (2009), informal tangible support provided by fellow church members is associated with better health condition but only for older adults who are more deeply committed to denomination they belonged. Although there are variations in the ways these older people assist one another within the church circuit, the informal supports which are usually health supports, are provided to fellow members when they are more deeply committed to the church which they belong. A place of worship, in addition to its spiritual significance, is often a location where social interaction happens, friends meet, families gather, and supportive activities take place (Zimmer et al., 2016). Studies have shown that people who are widely involved and committed to these social ties and interactions are more likely to benefit from church-based networks and relationships (Krause, 2008; Taylor, Chatters and Levin, 2004; Taylor, Lincoln and Chatters, 2005).

Individuals who are closer to fellow church members and also attend religious services at least once every week are the least likely to report suicidal ideations as a result of information and emotional social support available to them; whereas those who attend services a few times a year are the most likely to report suicidal ideations (Chatters et al., 20I I). On the other hand, Krause (2010) found that at relatively low levels of exposure to stress, older Protestants are more likely than older Catholics to get emotional support from either rank-and-file church members or members of the clergy. Nevertheless, as the level of exposure to stress increases, this difference disappears, and older Catholics appear to be just as likely as older Protestants to receive emotional support from fellow church members and members of the clergy.

Congregational interconnectivity or possessing a sense of shared identity and purpose, and ability to work together toward a common objective, is another factor that enhances social support relationships between members (Hayward and
Krause, 2013). For Haslam et al., (2009) group members who are more cohesive and always provide a strong sense of identity to their fellow worshipers, are more supportive, and provide more opportunities to give support to other members, compared with groups that are divided by conflict or lack of clear identity.

Social exchange theory set forth by George Homans (I96I) was adopted to provide theoretical framework for this study. The theory is considered relevant to the study because of its usefulness in understanding the provision of social support to older adults by various support networks including churchbased organisations. Social exchange theory is based on the notion that the balance of rewards and costs of behaviour to the individual and society predicts the overall behaviour of older adults. This theory has been applied in the field of gerontology, especially in the works of Burnight and Mosqueda (20I I); Okoye and Asa (20I I); Perel-Levin (2008) and Tanyi (20I4). Social exchange theory is concerned with interaction or transaction between two or more people as they seek to maximize rewards and minimize costs in their interactions. Society is made up of different actors who are of different age-groups/grades, which include the old, the young, and the children. These actors are pursuing a common goal which is to survive in every relationship they are in. Most relationships take the form of give and take, though the balance of the exchange may not always be equal. In as much as most people who are in a relationship are giving something, the desire is to get in exchange something that will be beneficial to them. These benefits can be either material, such as money and property or other benefits such as affection, prestige/recognition, status, and approval (Chappell et al., 2003; Michener, DeLamater and Schwartz, 1986).

Social exchange theory explains the notion behind the role of church-based organisations regarding provision of social support and care to their older members. Church-based organisations are predicted to meet the needs of older adults who are members only as long as the older adults contribute immensely to the church. The older adults in their active phase of life were committed and actively participated in activities that engendered the growth and functionality of their churches. They contributed money, time, materials, knowledge etc. to ensure the stability and efficiency that their churches are enjoying today. The basis for church support and care to them hinges on the enormous efforts and labour put out by these older adults to their various churches during their active phase of life.

In as much as social exchange theory is based on reward concepts or focus on cost and benefits of a 
relationship, scholars like Hollis-Sawyer (200I) stated that individual differences and not necessarily cost and benefits of a relationship are more important contributory factors in understanding issues that occur during support and care for older adults. Also, Geister (2005) found that many people who care and support older adults do so as a moral duty and because of feeling or responsibility and not necessarily as a result of what they hope to gain or what they have gained from the relationship. In the same vein, Zafirovski (2005) posit that social exchange theory is based on reward concepts, but all cultures are different and in some cultures, they may not seek a reward for a relationship.

\section{Data and methods}

The study was carried out in Nnewi, South-east Nigeria. Nnewi comprises of four villages: Otolo, Uruagu, Umudim, and Nnewichi. Geographically, Nnewi falls within the tropical rain forest region of Nigeria, which gives it the ecological basis for production of a wide range of tropical agriculture crops (Nnewi Union Atlanta, 2008). The main occupation of Nnewi people is trading and farming.

Religion plays a pivotal role and occupies a central place in the heart of the people. This is manifested in the numerous churches and other religious activities in the town. The people of Nnewi are predominantly Christians, with small fractions of the people belonging to other faiths like traditional religion, Islam, among others. These religious groups have in one way or the other contributed to the provision of social support for older adults in the town. However, church-based organisation was adopted in this study because Christianity is the most dominant religious groups in south-eastern part of Nigeria. Additionally, there was need to streamline the focus to a manageable scope as including the roles of other religious organisations would make the study too complex to handle. Also, the choice of Nnewi town as the study area was as a result of its strategic location and ability to attract people from different localities for different socio-economic activities. Thus people of diverse church denominations come to work, trade, and live in the town. This enhanced the opportunity to elicit information from different older adults who are both indigenes and non-indigenes but who reside at Nnewi.

The study adopted cross-sectional design. The sample of 40 participants comprising of 24 older adults and 16 caregivers were purposively selected for this study. Eight respondents (older adults, 60 years and above) comprising of four males and four females were purposively selected for In-depth Interview (IDI). For the Focus Group Discussion
(FGD), four FGDs were conducted with older adults and their caregivers. This comprised of older adults who were 60 years and above and their caregivers who were 18 - 49 years. For the FGDs with older adults, eight male participants were selected from one of the four villages - Otolo and eight female participants were also selected from one of the three remaining villages- Uruagu. For the FGDs with the caregivers, eight male participants were selected from one of the two remaining villages- Umudim while eight female respondents were selected from the remaining village $\neg \neg-$ Nnewichi.

The IDI schedule and FGD guide served as the instruments for data collection. The choice to adopt IDI and FGD as the instruments for data collection was informed by the dispositions of some older adults as some may not want to discuss their private life to the hearing of other community members. The IDI schedule and FGD guide contained unstructured questions which allowed researchers probe for further responses from respondents. The interview and discussion sessions were audio taped, while a research assistant was jotting down the non-verbal cues such body gesture, nodding of heads, frowning of faces etc and vocal responses of same participants. The data collected were analyzed in themes. The data were transcribed first in lgbo language and translated into English to ensure that English and Igbo language versions carried the same meanings. In going through the transcription, phrases with special meanings were identified and used as illustrative quotes.

\section{Ethical considerations}

The study instrument and methodology was approved by the Ethical Review Board of the University of Nigeria, Nsukka. Oral informed consent was sought and obtained from each participant prior to recruitment.

\section{Results}

The data on Table I below shows the sociodemographic characteristics of the respondents with equal percentages in gender. The data revealed also that $40 \%$ of the respondents were between the ages of 18 to 49 years while $60 \%$ were between the ages of 60 and above. The findings also revealed that $62.5 \%$ were married, $32.5 \%$ were widowed, and only $5 \%$ were not married. Furthermore, $30 \%$ of the respondents had no formal education, $30 \%$ had primary and secondary education while $10 \%$ had tertiary education. The findings also indicated that $2.5 \%$ of the respondents were unemployed, $7.5 \%$ were farmers and retirees, $72.5 \%$ were selfemployed while $10 \%$ were civil servants. 
Table I: Socio-demographic characteristics of respondents

\begin{tabular}{lll}
\hline Demographic data & Frequency & Percentage \\
\hline Sex & & \\
Male & 20 & 50 \\
Female & 20 & 50 \\
Age & 16 & 40 \\
I8-49 & 24 & 60 \\
$>60$ & & \\
Marital status & 25 & 62.5 \\
Married & 13 & 32.5 \\
Widowed & 2 & 5 \\
Single & 0 & 0 \\
Divorced & & \\
Education & 12 & 30 \\
None & 12 & 30 \\
Primary & 12 & 30 \\
Secondary & 4 & 10 \\
Tertiary & & \\
Occupation & 1 & 2.5 \\
None & 3 & 7.5 \\
Farmer & 3 & 7.5 \\
Former employed & 29 & 72.5 \\
Self employed & 4 & 10 \\
Civil servant & &
\end{tabular}

Source: Fieldwork 2016

Views on the importance of social support and care to older adults

The researchers tried to ascertain if the participants were knowledgeable about the importance of social support and care to older adults. The findings from the study revealed that majority of the participants indicated that social support is very essential to older adults. While some of the participants reflected that social support and care received by older adults will enable them live a good life, some other participants indicated that social support will prevent older adults from frequent sickness. One of the participants in FGD conducted with male older adults reflected:

There are many benefits attached to social support, it makes older adults feel happy all the time. It also makes them not to be susceptible to all forms of sickness and thereby live more prolonged life.

Also, another male participant in an FGD with caregivers reflected:

When you talk about social support, it entails those amenities that make people comfortable and at ease with life. It also involve the basic life requirements needed by older adults which they receive from the community, government, fellow human beings and any other institution like churches etc. the support could be health facilities, it could be materials in form of food, water, transportation, and recreational programmes which will make an elderly person live a good life.
Views on forms of support and care provided to older adults by church-based organisations

The researchers sought to find out the support and care provided by church-based organisations to older adults and their various forms. The findings revealed that the participants receive various support and care from the church on an on-going basis. Some of the participants indicated that they receive material, information, health, financial and emotional supports. Others voiced that their churches periodically organize teaching programmes on health and healthy lifestyles. Equally, some opined that they do receive food items and sometimes, money from the church. However, the participants indicated that older adults who are not members of the church are invited during teaching programmes but are left out when other support like money, food items, clothes are provided. Other participants stated that officials from the church do visit, pray, and also administer Holy Communion to them in their respective homes. Some of the participants' views on the forms of support they receive are reflected thus:

\section{Information Support}

The church also organize teaching programmes for us from time to time, and occasionally invite people who are not members of the church to learn how to maintain our health.(Female older adult, FGD). 
Also, another male older adult in an IDI stated:

They (church) also provide social support for older adults. For instance, the churches will always support people with information that will help to develop their mind, and support indigent older adults. Unfortunately, some churches are not living up to expectations nowadays.

\section{Material Support}

One of the female participants in an FGD conducted with older adults reflected on the material support they receive:

Social support in this community involves assistance given to older adults who are in need or who do not have anybody to help. The support could be received from either individuals or churches. For instance, in this community, some churches take up projects where houses are erected for older adults who are homeless.

Also, another female older adult in IDI reflected:

I receive social support from church especially in our church (St. Martins Catholic Church). They usually give us free medication and sometimes they offer material support like bags of rice, and other foodstuffs.

\section{Emotional Support}

Another support we receive is prayer and visitation through our church. The church sometimes visits the older adults to offer words of encouragement and prayer. The church also gives out material gifts to the older adults when they visit us. (Male older adult, IDI).

A male older adult in an IDI stated that he receives more of prayer as a catechist. He stated thus: "I am a catechist in Roman Catholic denomination, so I receive more of prayers from the church". Meanwhile, a female participant in FGD with older adults reflected on the financial cum health support she receives from the church, and stated thus: "Even when we do not have money to pay hospital bills, we have no other option than to meet with our parish priest for the church to support us in paying the bill”.

Views on whether the support services are available to older adults who are non-members of the particular church in Nnewi.

The researchers put forward questions to ascertain if the support and care available to older adults from the church-based organisations are accessible to nonmembers of the particular church. The findings from the study revealed that not every older adult receives support and care from the church. Some of the respondents indicated that much of the church-based support and care goes to members of the particular denomination that the older adult belongs. Churchbased organisations are particularly interested in providing support and care to the indigent members who are home bound, and the widows who are members of the church. Some of the respondents' views are reflected as follows:

The churches where the older adults worship support them especially when they are home bound and indigent. The church periodically visits to pray with them and also encourage them. Sometimes gifts may include cash and or material gifts (A female respondent in FGD with care-givers).

Another female participant in FGD with older adults reflected:

Church will support committed older adults who cannot provide for themselves. I have been provided with monetary support whenever the members of my church visit me to pray with me. The church did this to some of us because when we were young, we used to be active members of the church. She refrains thus: "church pampers us because we were active members of the church at our youthful age".

Also, a female participant in FGD with older adults reflected,

Yes, in our church, we do receive financial and health support, at St. Martin church (Roman Catholic), hospital was built for the indigents in the society for their medical care. The church also assists people to pay their bill after treatment in other hospitals; this support is for indigent older adults and the children who are members of the church (St. Martin).

A male participant in FGD conducted with caregivers equally reflected,

Some older adults receives financial assistance from churches especially the denomination the older adults belong to. Sometimes churches will identify the home bound and indigent older adults they want to visit in the community. They will pray with them, administer Holy Communion for them and also dispense cash and material gifts to them. Yes, church do visit their members who are old and cannot be able to come to service as a result of old age and sickness, they are also given holy communion and other spiritual blessing.

Views on frequency of church-based support and care to older adults.

The researchers tried to find out how frequent church-based organisations provide support and care to older adults. The findings revealed that despite the efforts of church-based organisations to support and care for older adults, the support and care are not frequent. While some of the participants stated that the support and care comes to them randomly, other participants indicated that they usually receive 
support during festive periods. For instance, a male participant in FGD conducted with older adults reflected that:

Individuals from the community do bring material gifts periodically to be shared among the widows and indigents. Sometimes, they bring money to be shared to the families that cannot afford the school fees of their children. In this church, we have received such support through the Anglican Diocese of Nnewi. The diocese will request that individuals donate money, foods, their fairly used clothes, shoes etc. after collating them, they will give them out to those older adults who are in need.

Equally, a female older adult in IDI stated:

Of course, we do receive material support like clothes and food from our churches, though not always but predominantly during festive periods like Christmas, New Year, Easter and Mothers Sunday. Some older adults do receive material support from the community members but not always; it may take long time for such support to come.

Another female older adult in IDI stated that "the church sometimes provide material support such as food, clothes and food stuff to older adults, but such support are often received during festive periods".

More so, a male participant in FGD with older adults reflected:

Somebody may have pressing need requiring urgent attention; the diocese/bishop (Anglican) will issue a letter to the person to enable him/her to solicit for support from churches in the diocese.

\section{Discussion}

Our survey explored the role of the church in the support and care of older adults in Nnewi South-east, Nigeria. The findings from this study indicated that social support is very essential to the well-being and life satisfaction of older adults. The social support and care received are equally essentials tools for improved standard of living and general well-being of older adults. Social support also makes life worth living for older adults and also helps to prevent frequent sickness. These findings are in line with the findings of Okoye and Akinyemi (2009) who noted that social support helps older adults in achieving and maintaining a sense of well-being and satisfaction in life. Assari (2013) also noted that church-based social support is also extremely beneficial for health and well-being. Holt-Lunstad et al. (2010) found in their study that social support enables older adults survive various forms of diseases such as cancer, cardiovascular disease, and inflammation, as well as less effective immune system functioning.

The findings of this present study revealed that church-based organisations provide information and health support to older adults. The church occasionally organizes teaching programmes for older adults to learn how to maintain their health. Also, the church assists older adults to pay their hospital bills when they are sick. The findings of this study are consistent with other studies such as that of Kim et al. (2015) who found that church-based organisations were important network connections for Korean Americans to obtain relevant information regarding their health. Taylor (2017) also noted that churchbased organization assists members when they are ill more than any other type of support.

The findings of the current study revealed that older adults are provided with emotional support from church-based organisations. The church-based organisations sometime visit their older adult members to pray with them and offer words of encouragement to them. This finding affirms the assertion of Taylor et al. (2005) who found that church-based support networks provide significant amount of non-tangibles support such as emotional support, counseling and advice. Kim et al. (20/5) also found that church-based organisations were important network connections for Korean Americans to obtain emotional support and companionship. Krause (2008) noted that churchbased support networks provide assistance and resources, emotional and psychosocial support that are essential elements in coping with life problems and stressful events. Hood et al. (2017) equally noted that church members seek to address their emotional support needs through spiritual support exchanges with their network members, such as praying together and sharing the word of God together.

Social exchange theory was adopted to provide theoretical framework for this study. Social exchange theory is concerned with interaction or transaction between two or more people as they seek to maximize rewards and minimize costs in their interactions and relationships. In as much as most people are giving something in their relationship, the desire is to exchange for something that will be beneficial to them. These benefits can be either material, such as money and property or nonmaterial, such as affection, emotional, social, prestige, status, and approval (Chappell et al., 2003; Michener et al., 1986). These assertions of exchange theory conforms to the findings of the current study which revealed that aside information support, other support and care available for older adults in Nnewi south-east, Nigeria were not all-inclusive. It indicated that support to older adults from church based organisations were limited to those of them who were members of a given denomination as well as committed members of the church. These members as reflected in the finding were older adults who in their active phase of life were committed and also 
actively participated in activities that supported the growth and functionality of the churches they belong. Their support and contributions to their various churches in their active phase of life certainly have played significant role in the support and care they receive from their various churches especially in their old age.

The findings of this study equally revealed that church-based organisations often provide social support and care to the indigents, the home bound, and the widows who are members of the church. The church-based organisations usually provide the older adults with cash and or material gifts. Sometimes, these support were given by wealthy individuals in the community through the church. , They also help in building houses for those older adults who are homeless, and offer to train their children. These findings is in agreement with the findings of Wuthnow (2002) who noted that belonging to a religious congregation provides individuals with the opportunity to receive support and is also an avenue through which the affluent members provide for the less privileged. Such level of mutual interaction form the bases upon which bonding is defined and social capital gap bridged. It facilitates both horizontal and vertical relationships and acts as a conduit through which less privileged members receive aid from members of a higher socio-economic status outside the church.

The current study equally revealed that aside information support, every other social supports such as finance, emotional, material etc provided by church-based organisations are exclusively at the reach of older adults who are members of a particular church network. In conformity with other studies such as that of Krause and Bastida (20I I) who found that older African Americans were more likely than both older whites and older Mexican Americans to receive both emotional, spiritual and instrumental support with congregational members. In addition Krause (2016) found that African American adults were significantly more likely than whites and Hispanics to receive emotional support and spiritual support with congregants. Taylor et al. (20/3) found that African Americans had more frequent contact, were subjectively closer and provided general support to their congregation members more frequently than non-Hispanic whites.

\section{Conclusion}

This study explored the role of church-based organisations in the support and care of older adults in Nnewi town, south-east, Nigeria. Social support was found to be beneficial to the wellbeing and life satisfaction especially in old age. Available social supports from church-based organisations help older adults minimize the problems affecting their emotional, physical, social, economic, and psychological wellbeing. From this study, it can be inferred that older adults receive various forms of social support from church-based organisations. These supports include information, materials, financial, health, and emotional support. However, some of the church-based support and care were exclusively provided to older adults who are members of particular denominations. Also, churchbased organisations are keenly interested in providing support and care to their indigents, home bounds, and widows who are members of the church. Despite the efforts put up by church-based organisations to provide support and care to older adults, the support and care are not frequent but periodical; usually during the festive periods or when pressing needs arise.

The results of this study therefore add to other surveys that advocate for welfare programmes and policies that address an all-inclusive and holistic support and care for older adults in the Nigeria irrespective of the denomination older adults belong. These supports and cares through policies and programmes will to a large extent act as buffer against poverty and hunger ravaging Nigerian older adults, thereby achieving the road map of Sustainable Developing Goals (SDGs) in Nigeria. In the same vein, church-based organisations that spearhead campaigns for love and unity should endeavour to extend their supports and care to every older adult without limiting some of their support to only older adults who are their members. Equally, church-based organization should pay frequent visits to older adults at their various homes to ascertain their burden and life challenges, this will in turn give the older adults a sense of identity. Regular seminars and teachings should be organized for older adults during church worship or any other suitable days of the week, to educate them on self-care, nutrition, health tips and the need for personal hygiene.

This study, however, failed to ascertain the source(s) of fund for these church-based organisations and the reasons for their non- frequent support and care to older adults as expected. Perhaps, this current study however is not devoid of limitations, and thus, recommends for subsequent studies to be carried out regarding non-frequent provision of support and care by the church-based organisations.

\section{Funding}

The author(s) received no financial support for the research, authorship, and/or publication of this article. 


\section{References}

Agubuzu-Oyi, C. M. (20|4). Widowhood Practice in Ezeagu, Nigeria: The Role of the Anglican Church. [Online], MSc. South African Theological Seminary. Available at: https://www.sats.edu.za/wpcontent/.../AgabuzuT_Final-MiniThesis-Apr2015I.pdf [Accessed 18 Dec. 2017].

Ahmad, A. (2016). Life Satisfaction versus Social Support among Aged: An Overview. Psychology and Behavioral Science International Journal, [online] I(4), pp. 00I-005. Available at: http://www.juniperpublishers.com >pbs.

[Accessed 6 Dec. 2014].

Assari S. Race and ethnicity, religion involvement, church-based social support and subjective health in United States: A case of moderated mediation. International Journal of Preventive Medicine, 4, pp. 208-2 17. [PubMed: 2354379I]

Baiyeri, H. B. (20|4). The Role of Faith-Based Organizations (FBOS) in Human Development: A Study of Kogi State. [Online] MSc. University of Nigeria, Nsukka. Available at: http://www.unn.edu.ng/publications/files/BAIYERI, \%20H.\%20B.pdf. [Accessed I8 Dec. 20I7].

Bath, P. A. and Deeg, D. (2005). Social Engagement and Health Outcomes among Older People: Introduction to a Special Section. European Journal of Ageing, 2, pp. 24-30.

Billingsley, A. (1999). Mighty like a river: The black church and social reform. New York, NY: OxfordUniversity Press.

Boehm, S., Coleman-Burns, P., Schlenk, E. A., Funnell, M. M., Parzuchowski, J. and Powell, I. J. (1995). Prostate Cancer in African American Men: Increasing Knowledge and SelfEfficacy.J Community Health Nurs., 12, pp. I6I-169.

Burnight, K., and Mosqueda, L. (20II). Theoretical Model Development in Elder Mis $\neg$ treatment. Document [online] 234488. Award 2005-IJ-CX0048.

Available

at: https://www.ncjrs.gov/pdffiles I/nii/grants/234488. pdf [Accessed 25 May 20I8].

Caetano, S. C., Silver, C. M. F. P. and Vettore, M. V. (2013).Gender Differences in the Association of Perceived Social Support and Social Network with Self-Rated Health Status among Older Adults: A Population-Based Study in Brazil. Boston Medical Center Geriatrics,[online] 13, pp. 122. Available at: http://www.biomedcentral. com //47|23/8/I3/I22. [Accessed I 2 May 20I5].

Campbell, M. K., Demark-Wahnefried, W., Symons $M$, et al. (1999). Fruit and VegetableConsumption and Prevention of Cancer: The Black Churches United for BetterHealth Project. Am J Public Health,89, I390-1 396.
Chappell, N., Gee, E. McDonald, L. and Stone, M. (2003). Aging in contemporary Canada. Toronto, Ontario: Prentice Hall.

Chatters, L. M., Taylor, R. J., Lincoln, K. D., Nguyen, A. and Joe, S. (20II). Church-Based Social Support and Suicidalityamong African Americans and Black Caribbeans. Archives of Suicide Research, [online] 15(4), pp. 337-353. Available at: [Accesses 27 Sep. 2017].

Chatters, L. M., Taylor, R. J., Lincoln, K. D. and Schroepfer, T. (2002). Patterns of Informal Support from Family and Church Members among African Americans. Journal of Black Studies, 33, pp. 66-85.

Chatters, L. M., Taylor, R. J., Woodward, A. T. andNicklett, E. J. (20I5). Social Support from Church and Family Members and Depressive Symptoms Among Older African Americans. The American Journal of Geriatric and Psychiatric, [online] 23(6), pp. 559-567.DOI: http://dx.doi.org/I0.1016/j.jagp.2014.04.008

Costa, S. V., Ceolim, M. F. and Neri, A. L. (20II). Sleep Problems and Social Support: Frailty in a Brazilian Elderly Multicenter Study. Revista LatinoAmericana de Enfermagem, 19, pp. 920-927.

DeHaven, M. J., Hunter, I. B., Wilder, L., Walton, J. W. and Berry, J. (2004). Health Programs in FaithBasedOrganizations: Are they Effective? Am J Public Health, 94, pp. I030-1036.

Dimelu M. U., Salua E. S. and Igbokwe E. M. (20/3). Performance of Faith-Based Grassroot NonGovernmental Organisations in Rural Development in Nasarawa State, Nigeria. International NGO Journal, [online] 8(7), pp. I46152.Available

at: http://www.academicjournals.org/journal//NGOJ/a rticle-full-text-pdf/7C8F8884I574 [Accessed I8 Dec. 20I7].

Dodson, A. C. (2009). Social Support at Community Centers: Its Meaning in the Lives of Senior Citizens.MSc.Virginia Polytechnic Institute and State University.

Dowd, J. J. (1984). Beneficence and the Aged. Journal of Gerontology, 39, pp. 102-108.

Dowd, J. J. (1975). Aging as Exchange: A Preface to Theory. Journal of Gerontology, 30, pp. 584-594.

Duan, N., Fox, S. A., Derose, K. P. and Carson, S. (2000). Maintaining Mammography AdherenceThrough Telephone Counseling in a Church-Based Trial. Am J Public Health, 90, pp. |468-|47|.

Duru, O. K., Sarkisian, C. A., Leng, M. andMangione, C. M. (2010). Sisters in Motion: A RandomizedControlled Trial of a Faith-Based Physical Activity Intervention. J Am Geriatr Soc., 58, pp. 1863-1869. 
Ellis, J. L. and Morzinski, J. A.(20/3). Training Lay Volunteers to Promote Health in CentralCityAfrican American Churches. J Christ Nurs.,30, pp. I2-II6.

Evers, A. W. M., Kraaimaat, F. W., Geenen, R., Jacobs, J. W. G. and Bijlsma, J. W. J. (2003). Pain Coping and Social Support as Predictors of LongTerm Functional Disability and Pain in Early Rheumatoid Arthritis. Behaviour Research and Therapy, 3, pp. 1295-1310.

Geister, C.(2005). The Feeling of Responsibility as Core Motivation for Care Giving - Why Daughters Care for Their Mothers.Pflege, 18, 514.

Haslam, S. A., Jetten, J., Postmes, T. and Haslam, C. (2009). Social Identity,Health and Well-Being: An Emerging Agenda for Applied PsychologyApplied Psychology, 58, pp. I-23. doi:I0.1 III/j.14640597.2008.00379.x

Hawkley, L. C. and Cacioppo, J. T. (2007). Aging and Loneliness. Current Directions in Psychological Science, 16, pp. |87-91.

Hayward, R. D. and Elliott, M. (20I I). Subjective and Objective Fit in Religious Congregations: Implications for Well-Being. Group Processes and Intergroup Relations, I4, pp. I27-139. doi: | 0. I | 77/| 3684302 I037004 |

Hayward, R.D. and Krause, N. (2013). Changes in Church-Based Social Support Relationships During Older Adulthood. Journals of Gerontology Series B: Psychological Sciences and Social Sciences, [online] 68(I), pp. 85-96, Available at: doi:I0.1093/geronb/gbsI00 [Accessed 27 Sep. 2017].

Hollis-Sawyer, L. A.(200I). Adaptive, GrowthOriented, and Positive Perceptions of MotherDaughter Elder CaregivingRelationships: A PathAnalytic Investigation of Predictors. Journal of Women and Aging, 13, pp. 5-22.

Holt-Lunstad, J., Smith, T. B. and Layton, J. B. (20|0). Social Relationships and Mortality Risk: A MetaAnalytic Review. Publication Library of Science Medicine, [online]7,pp. I-2I. Available at: http://www.scholarsarchive.byu.edu/cgi/viewcont ent.cgi?article $=1093 \& \quad$ context $=$ facpub\# [Accessed I 2 June 20I6]

Homans, G. (196I). Social behavior: Its elementary forms. New York: Harcourt Brace Jovanovich.

Hood, S., Golembiewski, E., Benbow, K., Sow, H., and Thompson, V. S. (2017). Who Can I Turn To? Emotional Support Availability in African American Social Networks. Soc. Sci., [online] 6(I04), pp. I17. Available at http://www.mdpi.com/journal/socsci [Accessed 28 May 20I8].
Kim, W.,Kreps, G. L. andShin, C. N. (2015). The Role of Social Support and Social Networks in Health Information-Seeking Behavior Among Korean Americans: A Qualitative Study. International Journal for Equity in Health, [online] I4(I),pp. 40. Available at: http://www.equity healthj.com/content/14/I/40\#sec3. [Accessed 22 Jan 2015]

Kinsella, K. and Phillips, D. R. (2005). Global aging: The challenge of success. Population Bulletin, [online] 60(I), pp. I-44. Available at: http://www.prb.org/pdf05/60. I global aging.pdf [Accessed 22 Jan. 2015].

Krause, N. (2016). Assessing Supportive Social Exchanges Inside and Outside Religious Institutions: Exploring Variations Among Whites, Hispanics, and Blacks. Social Indicators Research, I28(I), pp. |3|-|46.

Krause, N., and Bastida, E. (20II). Social Relationships in the Church During Late Life: Assessing Differences Between African Americans, Whites, and Mexican Americans. Review of Religious Research,53, pp. 4I-63. [PubMed: 21998489].

Krause, N. (20/0). Receiving Social Support at Church when Stressful Life Events Arise: Do Catholics and Protestants Differ?PsychologRelig Spiritual,[online] 2(4), pp. 234-246. Available at: doi: 10.1037/a0020036 [Accessed 27 Sep. 2017].

Krause, N. (2009). Church-Based Volunteering, Providing Informal Support at Church, and SelfRated Health in Late Life .J Aging Health,[online] 2I(I), pp. 63-84. Available at: http://journals.sagepub.com/doi/I 0.1 I 77/0898264 308328638 [Accessed 27 Sep. 20I7].

Krause, N. (2008). Aging in the Church: How Social Relationships Affect Health. West Conshohocken, PA: Templeton Foundation Press.

Krause, N. (2006). Exploring the Stress-Buffering Effects of Church-Based Social Support and Secular Social Support on Health in Late Life. Journal of Gerontology: Social Sciences, 6I, pp. $35-43$.

Krause, N. and Hayward, R. D. (20I4). Church-Based Social Support, Functional Disability, and Change in Personal Control over Time. J Relig Health, [online] 53(I), pp. 267-278. Available at: doi:I0.1007/s| 0943-0|3-9707-0 [Accessed 27 Sep. 2017].

Kulik, C. T., Ryans, S., Harper, S. and George, G. (20|4). Aging population and management. Academy of Management Journal, 57, pp. 929934.

Li, H., Ji, Y. and Chen, T. (20/4). The Roles of Different Sources of Social Support on Emotional Well-Being Among Chinese Elderly. PLoS ONE, 
[online] 9(3), pp.I-8. Available at: http://www. flosone.org/articles/info\%3Adoi\%2F $0.137 / \% 2 \mathrm{Fj}$ ournal.pone.009005I [Accessed 22 Dec. 20I6].

Lincoln, C. E. and Mamiya, L. H. (1990). The Black Church in the African American experience. Durham,NC: Duke University Press.

Melchiorre, M. G., Chiatti, C., Lamura, G., TorresGonzales, F., Stankunas, M., Lindert.J..., Soares, J. F. (20/3). Social Support, Socio-Economic Status, Health and Abuse Among Older People in Seven European Countries. PLoS ONE, [online] 8(I), pp. I-10. Available at: http://www.ncbi.nlm.nih.gov /pmc/articles/PMC3559777/ [Accessed 19 Feb. 20I5].

Michener, H. A., DeLamater, J. D. and Schwartz, S. H. (I 986). Social psychology. San Diego: Harcourt Brace Jovanovich.

Mugweru, M. (20II). The Christian health association of Nigeria. Africa Christian Health AssociationsUpdate, [online] 16, pp. I-8. Available at

www.africachap.org/x5/images/stories/fruit/ 16 th \%20edition\%20english.pdf[Accessed 30 May 20I8]

Nnewi Union Atlanta (2008). Introduction to Nnewi. [Online] Available: http://www.nnewi union atlanta.8m.com/index.html [Accessed 2l Jan. 2015].

Okoye, U. O. (20/2). Family Care-Giving for Ageing Parents in Nigeria: Gender Differences, Cultural Imperatives and the Role of Education. International Journal of Education and Ageing, 2(2), pp. I39-154.

Okoye, U. O., andAkinyemi, A. (2009). Willingness of Youths to Support Aged Parents: A Study of Undergraduate in South-Eastern Nigeria. Nigerian Journal of Social Sciences, 5(2), pp. I0I-I I4.

Okoye, U. O., and Asa, S. S. (20II).Caregiving and Stress: Experience of People Taking Care of Elderly Relations in South-Eastern Nigeria. Arts and Social Sciences Journal, 29,pp. I-9. I

Okumagba, P. O. (20II). Family Support for the Elderly in Delta State of Nigeria. Studies on Home and Community Science, [online] 5(I), pp. 2I-27. Available at: http://www. Krepublishers.com/.../HCS-05-I-02 I I-I 46 [Accessed 28 May 2014].

Oladeji, D. (20II). Family Care, Social Services, and Living Arrangements Factors Influencing Psychosocial Well-Being of Elderly from Selected Households in Ibadan, Nigeria. Education Research International, [online] 20II, pp. I-6. Available at: http://www. hindawi.com/journals/edri/20I l/42 I898/

[Accessed I8 Nov. 2014].
Oluwagbemiga, O. (20I6). Effect of Social Support Systems on the Psychosocial Well-Being of theElderly in Old People's Homes in Ibadan. Journal of Gerontology \& Geriatric Research, [online] 5(5), I-9. DOI: $\quad$ 10.4I72/2I677I82.1000343 [Accessed 28 Sep. 20I7].

Perel-Levin, S. (2008). Discussing Screening for Elder Abuse at Primary Health Care Levels. Geneva, Switzerland: WHO Press.

Roh, S., Kim, Y., Lee, K. H., Lee, Y., Burnette, C. E.and Lawler, M. J. (20|5). Religion, Social Support, and Life Satisfaction among American Indian Older Adults. Journal of Religion \& Spirituality in Social Work: Social Thought, [online]34(4),Available

http://www.academic.oup.com>gnrl 03

[Accessed I8 Dec. 20I7].

Rokach, A., Orzeck, T. and Neto, F. (2004). Coping with Loneliness in Old Age: A cross-Cultural Comparison. Current Psychology, 23, pp. 124137.

Sijuwade, P. O. (2008). Elderly Care by Family Members: Abandonment, Abuse and Neglect. The Social Sciences, 3(8), pp. 542-547.

Tanyi, L. P. (20/4). Human Immunodeficiency Virus and Acquired Immune Deficiency Syndrome (HIV/AIDS) Burden on the Elderly Population in North West Region of Cameroon. PhD. University of Nigeria, Nsukka.

Taylor, R. J. (2017). Church-Based Exchanges of Informal Social Support among African Americans Race.SocProbl.,9(I), pp. 53-62. doi: | 0. | 007/s | 2552-0|7-9|95-z.

Taylor, R. J., Chatters, L. M. and Levin, J. (2004). Religion in the lives of African Americans: Social, psychological and health perspectives. Thousand Oaks, CA: Sage.

Taylor, R. J., Chatters, L. M., Woodward, A. T., and Brown, E. (20/3). Racial and Ethnic Differences in Extended Family, Friendship, Fictive Kin and Congregational Informal Support Networks. Family Relations,62, pp. 609-624. [PubMed: 25089067]

Taylor, R. J., Lincoln, K. D. and Chatters, L. M. (2005). Supportive Relationships with Church Members Among African Americans. Family Relations, 54, pp. 50I-5II.

Togonu-Bickersteth, F. and Akinyemi, A. I. (20/4). Ageing and National Development in Nigeria: Costly Assumptions and Challenges for the Future. African Population Studies,[online]27(2), pp. 36I-37I. Available at: http://aps.journals.ac.za/pub/article/view/48। [Accessed 10 Nov. 20I7].

United Nations, Department of Economic and Social Affairs, Population Division. (20/2). World 
Population Prospects: The 2010 Revision. [Online] Available at: http://www.un.org /esa/population/publications/20I2WorldPopAgeing Dev_Chart/2012PopAgeing and Dev WallChart.pdf.

World Health Organization (2002). Active ageing: A policy framework. WHO/NMH/NPH /02.8.

Wuthnow, R. (2002). Religious Involvement and Status-Bridging Social Capital. Journal for the Scientific Study of Religion, 4I, pp. 669-684. doi: | 0.1 | | |/|468-5906.00|53

Zhiya, S. J. D. (20I5).Pentecostal Churches' Response to the Plight of Widows in Federal Capital Territory, Abuja.[online], MSc. Ahmadu Bello University, Zaria, Nigeria. Available at:http://kubanni.abu.edu.ng:8080/jspui/bitstream/ 123456789/7482/I/PENTECOSTAL\%20CHURC HES\%E2\%80\%99\%20RESPONSE\%20TO\%20T HE\%20PLIGHT\%20OF\%20WIDOWS\%20IN\% 20FEDERAL\%20CAPITAL\%20TERRITORY\%2C \%20ABU]A.pdf [Accessed I8 Dec. 20I7].
Zafirovski, M. (2005). Social exchange theory under scrutiny: A positive critique of its economicbeviourist formulations. Electronic Journal of Sociology. Retrieved from http://www.sociology.org/content/2005/tier2/SET heory.pdf.

Zimmer, Z., Jagger, C., Chiu, C-T., Ofstedal, M. B., Rojo, F. and Saito, Y. (20I6). Spirituality, Religiosity,AgingandHealthinGlobalPers pective:AReview. SSM-Population Health,[online] 2, pp. 373-38I. Available at: https://ac.elscdn.com/S23528273 I6300 I79/I-s2.0-

S23528273 I 6300 I 79-main.pdf?_tid=9ac0997aa38I-Ile7-904b00000aa [Accessed 27 Nov. 20|7]. 